\author{
Žarko Paić \\ Sveučilište u Zagrebu, Tekstilno-tehnološki fakultet, Baruna Filipovića 28a, HR-10000 Zagreb \\ zarko.paic@ttf.hr
}

\title{
Nihilizam i povijest
}

\section{Što je preostalo od postmoderne?}

\begin{abstract}
Sažetak
U članku se uspostavlja korelacija između nihilizma i povijesti iz postavke o kraju metafizike u doba tehnosfere. Pokazujući genealogiju postmodernoga obrata u suvremenom filozofijskome mišljenju, autor se kritički razračunava s Vattimovom tezom da je Heideggerov pojam prebolijevanja metafizike (Verwindung) ključ za razumijevanje postmoderne. Unatoč neposredne blizine s Nietzscheom i Heideggerom, ipak je neporecivo da se glavni pojam mora izvesti iz mišljenja kasnoga Wittgensteina, kao što je to učinio Lyotard u analizi "postmodernoga stanja«. Posrijedi je pojam »jezičnih igara« koji uvodi u promišljanje odnos između pragmatike znanja, performativnosti jezika $i$ horizonta događaja. Na taj se način pokazuje da postmoderna nije nikakva vremenski određena "nova" epoha, već reaktualiziranje stanja kojeg određuje vladavina tehnoznanosti, kibernetike i pluralnih obrazaca kulture u postindustrijskome društvu. Autor na osnovi vlastitih prethodnih analiza ovog problema sabranih u knjigama Postmoderna igra svijeta, Politika identiteta, Posthumano stanje $i$ Tehnosfera I-V, smatra da jedino ekstenzivna analiza i tumačenje Lyotardovih postavki omogućuje dolazak na pravi filozofijski put spram odgovora na pitanje o biti nihilizma u suočenju s biti tehnosfere kao računanja, planiranja i konstrukcije neljudskoga. Ono što je preostalo od postmoderne u suvremenosti niti je "pričanje priča" o stilskim tendencijama moderne $i$ neomoderne, avangarde $i$ neoavangarde, niti, pak, sukob univerzalnosti i partikularnosti društva i kulture. Preostalo je jedino ono što ima karakter neotklonjive »sudbine" ovog nihilizma tehnosfere: od postmodernoga stanja do posthumanoga stanja mišljenje se nalazi pred izazovom događaja koji nadilazi sve viđeno u povijesti zapadnjačke metafizike. Kada slika prethodi jeziku, a pisanje govoru, nalazimo se u zatvorenome krugu obrata i preokreta metafizike. Vrijeme je za izlazak iz ovog "začaranoga kruga« u kojem živo postaje ne-živo, bitak informacijom, društvo sustavom objekata, a ljudsko-odveć-ljudsko neljudskim kao takvim.
\end{abstract}

\section{Ključne riječi}

postmoderni obrat, nihilizam, jezične igre, pragmatika znanja, posthumano stanje, Jean-François Lyotard, tehnosfera

\section{Uvod}

Tko želi razumjeti »silaznu putanju« zapadnjačke metafizike koja otpočinje uistinu s majstorima-misliocima »mračnoga 19. stoljeća« kao što su Nietzsche, Marx i Kierkegaard, taj se mora zaputiti sve do izvora ove duhovno-povijesne nelagode s kojom se susrećemo još i danas. Sjetimo se, naime, kako je za svu trojicu navedenih »anti-filozofa« simbol veličine i promašaja metafizike uopće Hegelova spekulativna logika apsolutne znanosti. Možemo je predočiti slikom neosvojive tvrđave koja se unutar vlastitih zidina urušava u samoj sebi. Zašto se to događa, to moramo tek obrazložiti. No, pojmovno-kategorijalno zdanje koje teži ovjekovječiti povijest kao ozbiljenje svjetskoga duha u samome »životu pojma« već je u ideji dospjelo do kraja povijesnih mogućnosti filozofije. Hegel je to jasno naznačio dalekosežno značajnom postavkom 
o »kraju povijesti«. Nije u toj misli samo iskazan sud o bitku i vremenu kao povijesnome odnosu od iskona Grka do utemeljenja modernoga svijeta s načelom vladavine znanstveno-tehnički određenoga uma koji zbilji propisuje uvjete mogućnosti i granice njezine protežnosti-u-svijetu. Problem je u tome što je postavka o »kraju povijesti« istodobno i postavka o »kraju umjetnosti« i »kraju filozofije«. Bez smisla i svrhe povijesti umjetnost se estetski zatvara $\mathrm{u}$ autonomiju vlastite bezbitnosti, dok se filozofija kao metafizika rastvara u kibernetici. Sve je to bilo još najavljeno Nietzscheovim projektom pokušaja prevladavanja nihilizma time što je glavni ontologijski pojam bitak rastvoren u pojam postajanje ili bivanje (Werden). Na taj se način povijesno zbivanje s prvim uzrokom i posljednjom svrhom preobrazilo u lutanje bez cilja s onom predivnom slikom iz spisa Radosna znanost, kada kaže da je pred nama »otvoreno more«. ${ }^{1}$ Budući da će se u drugome diskursu i kontekstu sve ovo postavljati iznova u prvi plan promišljanja povodom spora o moderni i postmoderni, pokušat ćemo iznijeti svojevrsnu genealogiju samoga problema koji nipošto još nije razriješen, a teško je za očekivati da će to i biti u dogledno vrijeme. Razlog tome leži u »biti« metafizike kao temelja za svekoliko povijesno zbivanje. Sve dok se ne razračunamo s njezinim nasljeđem u formi kibernetike, nije moguć izlazak iz začaranoga kruga »smisla« i »besmisla«. ${ }^{2}$ U mjerodavnome tumačenju Vanje Sutlića o odnosu Hegela i Marxa s obzirom na karakter metafizike i povijesti, pitanje o onto-logičkome karakteru povijesnoga zbivanja postaje odlučujuće pitanje o tome ima li povijest uopće smisla ili nema.

»Središnje pitanje svake filozofije povijesti jest upravo to pitanje: ima li povijest smisla, može li se nazrijeti svrha povijesnog zbivanja, je li ona neko napredovanje ili nazadovanje, postoje li posljednji, savršeni stadiji, posljednje stvari (eshaton, eshatologija) povijesti, postoje li uopće tendencije ili 'latencije' (rečeno Blochovim riječima) u povijesti - ili je to kaos, igra ljudskih strasti, kako kaže Hegel; da li je povijest besmisleni skup slučajeva ili je to smisleni kontinuitet (kontinuitet-diskontinuitet)? « ${ }^{3}$

Što se iz ovoga može nazrijeti? Ponajprije, da se s Hegelom uspostavlja razumijevanje čitave povijesti Zapada kao svjetsko-povijesnoga događanja polazeći iz »sudbine« filozofije kao metafizike. Formulacija je, dakako, izvedena u Heideggerovome mišljenju od kraja 1930-ih do kraja 1960-ih godina. Pojavljuje se i kada govori o Hegelu i Nietzscheu, ali i o Marxu. Pritom je razvidno da se »sudbina« ne misli kao slijepa nužnost nekog nadosjetilnoga gibanja koja čovjeka uzima pukom igračkom u svojim rukama. Bez slobode nema sudbinskoga događaja u povijesti. ${ }^{4}$ Naposljetku, i sama je metafizika povijesni događaj s binarnim oprekama »dobra« i »zla«, transcendencije i imanencije, ideje i zbilje. Unutarnja srodnost onoga što Sutlić pokazuje u predavanju o Hegelu - Marxu i onoga što čini Heidegger čini se jamstvom da se stvari postave radikalno. Metafizika se događa, dakle, samo i jedino kao »smisleno zbivanje«, kao izlaganje-razlaganje svrhe i cilja povijesti u onome posljednjem ili konačnome (teleologija i eshatologija). Stoga su svi izrazi tzv. sociologijskoga podrijetla poput »napretka« ili »progresa « $\mathrm{i} »$ nazatka « ili »dekadencije« povijesti već uvijek samo i jedino modifikacije onoga »istoga«. Riječ je, naravno, o bitku u njegovoj povijesnosti kao događanju smislenosti, čak i kada povijest postaje kaos i entropija, odnosno »buka i besmisao« u lutanju svjetova. Uostalom, nije slučajno čitav Hegelov naum povezivanja spekulativne dijalektike (pojma) i vjere u božansku moć ozbiljenja metafizike nazvan i »teodicejom svjetskoga duha «. ${ }^{5}$ Nije, međutim, problem u obrazloženju »uzlazne putanje« metafizike s njezinim temeljnim pojmovima od Pla- 
tona i Aristotela preko Descartesa, Leibniza, Kanta, do Schellinga i Hegela. Sve je ovdje »unaprijed « gotovo samorazumljivo, pa čak i to da su bitak i ništa jedno te isto, te da sloboda ne može biti utemeljena ni u kakvoj drugoj ideji osim u bezdanu vlastite ljudske egzistencije.

Poteškoće nastaju s onime što je nezadrživo na putu obesmišljavanja povijesti kao vladavine nihilizma u mnoštvu svojih likova. Kada povijest više nema smisla, a to znači da je dovedena u pitanje i svrha čitave metafizike i na njoj utemeljenih područja »duhovnoga bitka« od filozofije, umjetnosti, znanosti i religije, kao da slika urušavanja temelja one Hegelove tvrđave poprima nove simboličke i zbiljske slike. Kao da, naposljetku, sve što jest, tj. »bitak« više nema smisla, a otuda ni »vrijeme« jer, kao što bi to rekao Nietzsche, nedostaje i izostaje odgovor na pitanje »Zašto «?. ${ }^{6}$ Gubitak smisla povijesti ne proizlazi samo iz ljudskoga odnosa spram povijesnoga sklopa (bitka, biti čovjeka i bića u cjelini), nego i iz te gotovo fatalne nemogućnosti da se onome što se otpočelo »besmisleno« zbivati iznova vrati smisao. Može li se kaosu i entropiji doskočiti povratkom $\mathrm{u}$ »bit« metafizike tako da će se promijeniti smjer onoga što je još ostalo od povijesti ili je takav poduhvat unaprijed osuđen na propast? Čini se da je na tom tragu i promišljanje jednog od najvažnijih predstavnika tzv. slabe misli (pensiero debole) talijanske suvremene filozofije, Giannija Vattima, kada izričito u svojim spisima od kraja 1970-ih do kraja 1990-ih govori o postmoderni. Pritom je njegova analiza ovog problema povezana $\mathrm{s}$ hermeneutikom i poststrukturalizmom jer se često bavi analizom Nietzscheovih i Heideggerovih spisa, ali za razliku od Gadamera i Derridaa, primjerice, pristupa nihilizmu polazeći od razlikovanja temeljnog pojma Hegelove dijalektike kao što je »prevladavanje« (Überwindung - ukidanje i uzdizanje na viši stupanj) u odnosu na onaj koji rabi Heidegger u zbirci Vorträge und Aufsätze. Taj izraz jest pregorijevanje ili prebolijevanje (Verwindung). ${ }^{7}$ Ako se "prevladavanje« odnosi na unutarnje mogućnosti metafizike u njezinome

1

Friedrich Wilhelm Nietzsche, Die fröhliche Wissenschaft. Werke in drei Bänden, Carl Hanser Verlag, München 1954., sv. 2, str. 206. Vidi o tome: Žarko Paić, »Nietzsche i postmoderna kritika uma«, u: Žarko Paić, Traume razlika, Meandarmedia, Zagreb 2007., str. 13-30; Žarko Paić, Događaj i praznina. Ogledi o kraju povijesti, Izdanja Antibarbarus, Zagreb 2007.

2

Vidi o tome: Dean Komel, Obilježja smisla, prev. Mario Kopić, Litteris, Zagreb 2019.

Vanja Sutlić, Uvod u povijesno mišljenje. Hegel-Marx, Demetra, Zagreb 1994., str. 34.

4

Martin Heidegger, Holzwege, u: Martin Heidegger, Gesamtausgabe, sv. 5, Vittorio Klostermann, Frankfurt na Majni 2003.; Martin Heidegger, Vier Seminare, u: Gesamtausgabe, sv. 15, Vittorio Klostermann, Frankfurt na Majni 2005.
Karl Löwith, Weltgeschichte und Heilsgeschehen. Die theologischen Voraussetzungen der Geschichtsphilosophie, J. B. Metzler, Stuttgart 2004. Usp. Piere Chételat, »Hegel's Philosophy of World History as Theodicy. On Evil and Freedom«, u: Will Dudley (ur.), Hegel and History, SUNY Press, New York 2009., str. 215-230.

Martin Heidegger, »Nietzsches Wort 'Gott ist tot'«, u: M. Heidegger, Holzwege, str. 223.

Gianni Vattimo, »Nihilizam i postmoderna $\mathrm{u}$ filozofiji«, u: Gianni Vattimo, Čitanka, prev. Mario Kopić, Izdanja Antibarbarus - Hrvatsko društvo pisaca, Zagreb 2008., str. 123137. Valja kazati da je o tome u nas najsustavnije promišljeno u djelu Vanje Sutlića, Praksa rada kao znanstvena povijest. Povijesno mišljenje kao kritika kriptofilozofijskog ustrojstva Marxove misli, Globus, Zagreb 1987., str. 302-308. Naslov Sutlićeva članka dostatno o tome svjedoči: »Prebolijevanje filozofije i drugačija nakana povijesnog mišljenja«. 
»konstruktivnome« smislu izgradnje svagda »novih« i »naprednijih« $\mathrm{i} »$ razvijenijih« oblika i stupnjeva bitka u povijesnome smislu ozbiljenja ciljeva i svrha, onda je »pregorijevanje/prebolijevanje« pokušaj mišljenja izvan grani-

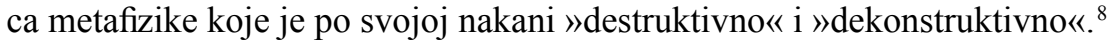

\section{O geneaologiji postmoderne}

Genealogija problema s kojim se suočava "postmoderna« uistinu je mnogo više od neke uklete verzije ponavljanja istoga, što su već u bitnome izveli Nietzsche, Marx i Kierkegaard. Mogli bismo, pritom, navesti kako su za prvoga estetski problemi metafizike »volje za moć« kao »vječnoga vraćanja jednakoga« gotovo istovjetni Marxovu mišljenju »biti« rada kao temelja vrijednosti, na čemu se zasniva ideja i zbilja kapitala u vremenu radno-tehničkoga otuđenja (Entfremdung), dok se, pak, za Kierkegaarda egzistencijalna vjera pronalazi kao prva i posljednja alternativa slobode spram ugrožene čovječnosti suspenzijom etičkoga u religioznome prostoru djelovanja. U sva tri slučaja posrijedi je razračunavanje $s$ »biti« metafizike, a ujedno su sva tri mislioca stvorili nove pojmove za pokušaj »prevrednovanja« vrijednosti, ozbiljenja filozofije u nadolazećoj zajednici proizvodnje »društvenosti« onkraj otuđenosti kapitalizma, te razotkrića subjektno-centrične egzistencije kojom tek moderno doba postaje uistinu »postmodernim«. Ako je Vattimovo nastojanje da se upravo s pomoću Heideggerova »prebolijevanja« metafizike izgradi novi pristup oslobađanju bitka od znanstveno-tehničke »sudbine« u suvremenosti, onda je riječ istodobno o nečemu što zacijelo zahtijeva temeljito propitivanje razloga zašto su i postmoderna i nihilizam korelativni u dva slučaja: (1) kada povijest gubi smisao i postaje kaosom i entropijom mnoštva i razlike; (2) kada povijesti u njezinom ubrzanome »napretku« $\mathrm{i} »$ razvitku $\ll$ na ishodu 20 . stoljeća nedostaje odgovor na pitanje »Zašto? «. Zašto, dakle, s postmodernom kao »silaznom putanjom « metafizike $u$ doba njezine realizacije sve smjera onome što Heidegger i Sutlić u svojim raspravama 1960-ih godina nazivaju stabilnošću u promjeni, a što je na izazovan način najinventivnije promislio u svojim analizama Gilles Deleuze? Pritom je stvorio čitav niz konceptualnih okvira i slika mišljenja primjerenih razdoblju tehnosfere: od razlike, sklopa, mnoštva, simulakruma, rizoma, postajanja ili bivanja (devenir), procesa, tijela-bez-organa, deteritorijalizacije/reteritorijalizacije itd. ${ }^{9}$

Korelacije koje iznosimo dokaz su da se priča o kontinuitetu-diskontinuitetu vremena ne može svesti na puko razlikovanje između »vjere u napredak« $\mathrm{i}$ »krize reprezentacije« jer to je sve već vrlo jasno postavio u horizont razmatranja Walter Benjamin u svojim Arkadama pitajući se zašto upravo u pojmu modernosti imamo dvije slike mišljenja, dvije pojmovne figure iz filozofije: prvu predstavlja Kant, a drugu Nietzsche. Prva se odnosi na bezuvjetnu vjeru u ljudsko usavršavanje i napredak, a druga je sumnja u smislenost povijesti kao linearnosti, kojoj se suprotstavlja ideja o vječnome povratku istoga. Obje slike mišljenja o bitku i vremenu samo su ono isto u razlici.

„Vjera u napredak, u beskonačno usavršavanje - beskonačnu zadaću u moralu - i predstava o vječnome vraćanju komplementarne su. Ovo su nerazrješive antinomije s obzirom na ono što razvija dijalektički pojam povijesnoga vremena. Usuprot tome, pojavljuje se predstava o vječnome vraćanju upravo suprotna 'plošnom racionalizmu' koji proizlazi iz vjere u napredak i utoliko je riječ o načinu mitskoga mišljenja istovjetnim predstavi o vječnome vraćanju. ${ }^{10}$ 
Kada to imamo u vidu, onda nam se nameće pitanje o tome je li u velikoj raspravi o moderni i postmoderni od kraja 1970-ih godina do uvjetno kazano kraja 20. stoljeća opravdano govoriti o »pobjedi« ili »porazu« prve ili druge koncepcije povijesti ili je to vrtnja u krugu, nešto što uistinu nije, unatoč zapaženih dostignuća u istraživanju ovih problema, doseglo razinu koju su uspostavili Nietzsche, Marx i Kierkegaard kritikom metafizike grosso modo i Hegela kao vrhunca spekulativne dijalektike? Ostavimo odgovor na to pitanje za kraj ovog razmatranja. Usmjerimo se sada razlozima zašto je upravo taj začudno sklopljeni pojam »postmoderne« izazivao toliko spora i nesporno velikog interesa među filozofima, sociolozima, teoretičarima arhitekture, književnosti, vizualnih umjetnosti, uključivši i teologe. Ne svjedoči li o tome gotovo apodiktičko izjašnjavanje je li netko u ovome ontologijsko-spoznajnome sporu, a koji ima i etičko-političke posljedice, na strani moderne ili postmoderne, pa sve do proglašavanja čitave struje mislioca mahom francuskoga, talijanskoga i američkoga kruga etiketama primjerice »postmodernoga pragmatizma«, kako se to uobičajeno pripisivalo američkome filozofu Richardu Rortyju. ${ }^{11}$ U Vattimovu razumijevanju problema otklanja se usmjerenost na tzv. probleme stila i »duha vremena« u umjetnostima. Namjesto toga pokušava se uvesti strogo i precizno filozofijsko razlikovanje modernosti i postmodernosti. Pritom nastaje dodatna poteškoća jer su ti pojmovi vezani uz »društvo« i »kulturu«. Stoga je nužno da se postmoderna razračuna s Frankfurtskom kritičkom teorijom. Nije, dakle, nimalo začudno zašto je polemika između Habermasa i Lyotarda imala za cilj obranu neobranjivoga: s jedne strane pojma »modernoga društva « kao središta estetske autonomije subjekta (Marx i Adorno), a s druge strane "postmoderne kulture « kao rastemeljenoga subjekta heteronomije i suverenosti događaja (Nietzsche i Heidegger). ${ }^{12} \mathrm{Z} e-$ lim ovdje samo napomenuti da su se i moja teorijska nastojanja od samoga početka vodila idejom da bez pojmovno-kategorijalnoga »utemeljenja« svaki razgovor o postmoderni ubrzo postaje »besmislena buka i naklapanje«, da se poslužim Kierkegaardovim izrazom u njegovoj kritici ispraznosti moderne zaokupljenosti izvanjskim i površinskim, ornamentalnim i estetski dopadljivim. Vidimo nešto naizgled začudno. Mislilac radikalne modernosti smatra

Vidi o tome iscrpno: Žarko Paić, »Pregorijevanje povijesti? Marx i Heidegger u 'novome vremenu' «, u: Ž. Paić, Događaj i razlika, str. 47-76.

Gilles Deleuze, Différence et répétition, Presses Universitaires de France, Pariz 2014. Vid o tome moje priloge u: Žarko Paić, Tehnosfera I-V, Sandorf i Mizantrop, 2018. - 2019.; Žarko Paić, White Holes and Visualization of the Body, Palgrave Macmillan, London - New York 2019.

10

Walter Benjamin, Das Passagen-Werk, u Walter Benjamin, Gesammelte Schriften, sv. 5, dio I, Suhrkamp, Frankfurt na Majni 1982., str. 178 (D10a, 5). Usp. Žarko Paić, Anđeo povijesti i Mesija događaja. Umjetnost-Politika-Tehnika u djelu Waltera Benjamina, Fakultet za medije i komunikacije, Beograd 2018.
11

Richard Rorty, Contingency, Irony, and Solidarity, Cambridge University Press, Cambridge - New York 1989. Usp. Barry Allan, »Postmodern Pragmatism. Richard Rorty's Transformation of American Philosophy«, Philosophical Topics 36 (2008) 1, str. 1-15.

12

Jürgen Habermas, Filozofski diskurs moderne. Dvanaest predavanja, prev. Igor Bošnjak, Globus, Zagreb 1987. Usp. Andreas Huyssen, Klaus R. Scherpe (ur.), Postmoderne. Zeichen eines kulturellen Wandels, Rowohlt Taschenbuch Verlag, Hamburg 1986.; Gvozden Flego (prir.), Postmoderna. Nova epoha ili zabluda, prev. Nadežda Cačinovič, Naprijed, Zagreb 1988.; Peter Kemper (prir.), Postmoderna ili borba za budućnost, prev. Dragutin Horvat, Dražen Pehar, Gordana Dana Grozdanić, August Cesarec, Zagreb 1993.; Marijan Krivak, Filozofijsko tematiziranje postmoderne, Hrvatsko filozofsko društvo, Zagreb 2000. 
upravo fenomene očitovanja te i takve modernosti ispraznim i nedostojnim mišljenja. Nije, stoga, neobično da se nova tumačenja Kierkegaarda ne odnose više na čitanja filozofije egzistencije u 20. stoljeću. Mnogo je više u središtu interesa ono što mnogi nazivaju »postmodernim obratom«. S njime se Kierkegaard preko Lévinasa i Derridaa uspostavlja ključnim arché za postmoderno rastemeljenje bitka, biti čovjeka i bića u cjelini. Isto se događa, naravno, s nasljeđem Nietzschea. Na to su upozorili, osim Vattima, već i francuski mislioci poput Pierrea Klossowskoga i Gillesa Deleuzea. ${ }^{13}$ Pojam je postmoderne skovan »nezgrapno«, inače ne bi mnogi mislioci poput najznačajnijih francuskih poststrukturalista već 1980 -ih godina, a među njima su reprezentativni Lyotard i Baudrillard, imali potrebu sa sebe skidati etiketu »postmodernista« i gotovo propedeutički objašnjavati što je to uistinu »postmoderno u moderni« te što za razliku od moderne vjere $u$ »velike priče « (duh, svijest, rad, želju) znači ulazak u doba vladavine tehnoznanosti i simulacije kao »kraja velikih priča ${ }^{14}$ Neki povjesničari kulture tvrde da je pojam bio u uporabi već u engleskog historičara civilizacija Arnolda Toynbeeja 1937. godine te da ga je zapravo prvi rabio 1934. godine Federico de Onís, antologičar španjolske i hispansko-američke poezije. ${ }^{15}$

Nezgrapnost proizlazi otuda što je prefiks »post« za razliku od onoga »neo« koji se počeo rabiti 1960-ih godina u takvim obratima kao što su neoavangarda, neorealizam, neomodernizam itd., upućivao na nešto što nije nipošto »novo« u smislu bezuvjetne novosti kao aktualnosti, već je u nekom neodređenome odnosu s njime i to kao pokušaj nadilaženja svake emfatičke uporabe modernosti u svijetu znanosti, tehnologije, umjetnosti, arhitekture, filozofije i književnosti.

Uglavnom, »post« je imao neskriveno podrijetlo onoga što je prijelazno, što ujedno označava moment kritike staroga i transgresiju novoga, kako je to možda najpreciznije izveo Georges Bataille u tumačenjima i komentarima uz Nietzschea. ${ }^{16}$ Prelazak neke imaginarne ili zbiljske granice ujedno je nešto »novo«, ali ta se »novost« može razumjeti tek kao renovacija i dekonstrukcija »staroga«. Primjerice, kada se želi vidjeti koliko kasni Husserlov pojam svijet života (Lebenswelt) ima značenje aktualnosti za kritiku suvremenoga kapitalizma u porobljavanju svakodnevice, potrebno je obnoviti njegovo shvaćanje intencionalnosti i intersubjektivnosti svijesti. No, istodobno valja zagraditi svaki mogući pristup koji bi podsjećao na »konzervativno« tumačenje odnosa života i kulture kakvi su bili uobičajeni u tzv. filozofijama života, od Diltheya do Spenglera. To znači da je "postmoderna« na paradoksalan i aporetičan način uistinu nešto drugo od puke kritike modernosti kao logike bezuvjetnoga napretka u onome što se smatra »društvom«, »kulturom« i »politikom«. Paradoks i aporija su figure koje je osobito »volio« Jacques Derrida, također jedan od ključnih mislioca, možda i sudbonosan za postmodernu jer je tvorac najučestalije raspravljanoga koncepta u suvremenoj filozofiji i društvenim i humanističkim znanostima - dekonstrukcije. ${ }^{17}$ Ukratko, ovim se pojmom, u razračunavanju s Heideggerovom »destrukcijom tradicionalne ontologije«, izvedene u njegovu glavnome djelu Bitak $i$ vrijeme iz 1927. godine, smjera razgradnji i rastemeljenju samog temeljnog načina kojim se bitak od Grka do Hegela poima kao prisutnost (ousia), što iziskuje promjenu ishodišta mišljenja. Utoliko dekonstrukcija pretpostavlja razumijevanje razlike (diférence) kao razlučivanja (différance). Složenost ove misaone djelatnosti izvodi se tako što se time pojmovi temelja, identiteta, subjekta, supstancije iz »temelja« 
dovode do preinake njihova mjesta i značenja u povijesti. Svaki se pojam zapadnjačke metafizike mora dekonstruirati. Iznimku čini jedino pravednost.

Za kasnoga Derridaa, mjesto je pravednosti izvan horizonta metafizike jer omogućuje smisleno djelovanje u zajednici, a nije izvedena iz slobode i jednakosti. ${ }^{18}$ Dekonstruirati samu ideju zapadnjačke povijesti utoliko znači dekonstruirati ono što čini »bit« nihilizma uopće. ${ }^{19}$

Sve ono što iziskuje »nova« tumačenja u posve drukčijem kontekstu od ranijeg razdoblja vladavine načela inovacije u znanostima i tehnologiji sada se premješta/razmješta. Kada dolazi do procesa ove ontologijske dislokacije nužno je uzeti u obzir semiotičku teoriju kulture. Ona počiva na postavci da je kultura glavni označitelj »kraja povijesti«. Stoga je značenje uvijek ovisno o kontekstu kulture kao partikularnosti. Ništa više nije unaprijed određeno, ni logika povijesnoga razvitka. Središnje se strukture »decentriraju« kao što je to bilo vidljivo u temeljnome pojmu subjekta Lacanove psihoanalize, a pojam dekonstrukcije za Derridaa označava vladavinu »logocentrizma« zapadnjačke metafizike. Tako umjesto djelovanja načela novovjekovne metafizike u Leibniza, kao što su računanje, planiranje i konstrukcija, u postmoderni pojavljuju se pojmovi transklasične logike. Uostalom, i Derrida ih spominje u njegovu glavnome spisu $O$ gramatologiji. Svi su prisvojeni iz kibernetike, biologije, informatike i lingvistike. »Bit« se »postmodernoga obrata« može otuda sažeti u postavci da pisanje-kao-trag prethodi jeziku kao govoru. Ono što je tehnički nadomjestivo i stoga »ne-živo« postaje, paradoksalno i aporetično, uvjet mogućnosti »živoga«. Razlika prethodi identitetu bitka kao što informacija prethodi svakoj kodiranoj komunikaciji u društvu i kulturi. Nestanak pojma prirode početak je vladavine anti-esencijalističkih teorija. Čak i današnji povratak ontologije realizma u suvremenoj filozofiji, s tzv. spe-

13

Žarko Paić, Sfere egzistencije. Tri studije o Kierkegaardu, Matica hrvatska, Zagreb 2017.

14

Jean-François Lyotard, La condition postmoderne. Rapport sur le savoir, Les Éd. de Minuit, Pariz 1979.; Jean-François Lyotard, Le postmoderne expliqué aux enfants. Correspondance, 1982-1985 (Débats), Galilée, Pariz 1986.; Francis Guibal, Jacob Rogozinski, Témoigner du différend, quand phraser ne se peut. Autour de Jean-François Lyotard, Osiris, Pariz 1989.; Jean-François Lyotard, L'Inhumain, Galilée, Pariz 1988.; Vidi o tome: Žarko Paić, Postmoderna igra svijeta, Durieux, Zagreb 1996.; Žarko Paić, Politika identiteta. Kultura kao nova ideologija, Izdanja Antibarbarus, Zagreb 2005.; Žarko Paić, Posthumano stanje. Kraj čovjeka i mogućnosti druge povijesti, Litteris, Zagreb 2011. Isto tako: Jean Baudrillard, Simulacija $i$ zbilja, prev. Rade Kalanj, Naklada Jesenski i Turk, Zagreb 2001.; Jean Baudrillard, Simulakrumi i simulacije, prev. Zlatko Wurzberg, Naklada Društva arhitekata, građevinara i geodeta, Karlovac 2001.

15

Paul Neubauer, »The Academic Reception of Postmodern American Literature in
Germany«, u: Theo D'haen, Hans Bertens (ur.), 'Closing the gap'. American Postmodern Fiction in Germany, Italy, Spain, and the Netherlands, Rodopi, Amsterdam - Atlanta 1997., str. 69-147, ovdje str. 80.

16

Georges Bataille, La Somme athéologique, Gallimard, Pariz 1992. O transgresiji vidi: Michel Foucault, »A Preface to Transgression «, u: Michel Foucault, Donald F. Bouchard (ur.), Language, Counter-Memory, Practice: Selected Essays and Interviews, Cornel University Press, Ithaca - New York 1977., str. 29-52. Usp. Žarko Paić, »Spirale transgresije: Georges Bataille i sveta profanost tijela«, u: Ž. Paić, Posthumano stanje, str. 429-471.

17

Jacques Derrida, De la grammatologie, Éditions de Minuit, Pariz 1967.

18

Jacques Derrida, Politiques de l'amitié. Suivi de l'oreille de Heidegger, Galilée, Pariz 1994.

19

Jacques Derrida, L'écriture et la différence, Seuil, Pariz 2014. 
kulativnim realizmom Quentina Meillassouxa ${ }^{20}$ nije srušio njihov prodor $\mathrm{u}$ različite društvene i humanističke znanosti.

$» \mathrm{U}$ istom značenju biolog danas govori o pismu i pro-gramu kada govori o najelementarnijim procesima informacije u živoj stanici. Naposljetku, postoje li ili ne bitne granice, svekoliko područje koje prekriva kibernetički p r o g r a m postat će poljem pisma. Za pretpostaviti je da teorija kibernetike može u sebi obuhvaćati sve metafizičke pojmove - sve do onih duše, života, vrijednosti, izbora, sjećanja - koji su se donedavno rabili kao suprotstavljanje stroja čovjeku, ona će, dok se njezina povijesno-metafizička pripadnost također objelodani, morati sačuvati pojam pisma, utiska, grama ili grafema. $\ll^{21}$

Što je bit onoga što smo nazvali »postmodernim obratom«? Ponajprije, i tu je bitna razlika mojeg shvaćanja spram Vattima i drugih na njegovu tragu, postmoderna se razlikuje od Heideggerova pokušaja mišljenja povijesnosti bitka polazeći od događaja (Ereignis). Da bismo to pojasnili nužno je reći da Vattimo uzima Heideggera za svjedoka svoje glavne postavke o »kraju moderne ${ }^{22}$ Kraj se ne može misliti drukčije negoli u okvirima metafizike, kao povijesno-epohalni događaj iščezavanja prethodne misaone sheme u cjelini. Obrat koji se ovdje pokazuje odnosi se na engleski izraz turn, što nipošto ne može biti adekvatan prijevod njemačkoga die Kehre koji je početak 1930-ih godina svih Heideggerovih misaonih figura »obrata«, »pregorijevanja/prebolijevanja«, »okreta« i »preokreta«. ${ }^{23}$ Dok se, dakle, u slučaju postmodernoga obrata u konačnici radi o vladavini slike nad jezikom, simulacije nad zbiljom, strukture nad životom, kibernetike kao sustava informacija nad kazivanjem jezika u egzistencijalnoj predbježnosti čovjeka kao tubitka (Dasein), Heidegger pokušava brižno preusmjeriti mišljenje povijesti metafizike kao nihilizma $\mathrm{s}$ onu stranu vladavine računanja, planiranja i konstrukcije. ${ }^{24}$ Postmoderni obrat, pak, samo je drugi naziv za pokušaj da se metafizika »dekonstruira«, »decentrira«, »dekontekstualizira «, dovede do mogućnosti rasklapanja njezina onto-teologijskoga sklopa i da se, naposljetku, umjesto logocentrizma Zapada i njegova shvaćanja svijeta uvede mogućnost razlike svjetova, polazeći od razgradnje svakog dosadašnjega temelja svjetovnosti svijeta. Ukoliko prihvatimo takvo shvaćanje, utoliko možemo reći da blizina između Heideggera i postmodernoga obrata, unatoč jezičnoj i terminologijskoj složenosti kazivanja kada je riječ o Derridau, Lyotardu, Deleuzeu te Vattimu, ipak nije tolika, koliko je uistinu između njih nepremostiv razmak u mišljenju. Nije, stoga, posrijedi prebolijevanje metafizike kao ključne riječi za postmodernu misao, već ipak nešto, da se izrazimo ironično-ciničnim jezikom Montyja Pythona, posve drukčije.

\section{Lyotard i jezične igre}

U nekoliko sam navrata nastojao obrazložiti zašto smatram da je za razumijevanje ovog problema jedino mjerodavno izložiti temeljne filozofijske uvide Jean-Françoisa Lyotarda, mislioca koji je paradigmatski za postmodernu u cijelosti. Njegov spisi Postmoderno stanje (La condition postmoderne) iz 1979. godine, potom Raskol (Le différend) iz 1983. godine, Postmoderna protumačena djeci (Le postmoderne expliqué aux enfants) iz 1986. godine, te Neljudsko (L'Inhumain) iz 1988. godine vjerodostojni su putokaz za promišljanje onoga što stoji u biti postmodernoga obrata. ${ }^{25}$ Nema sumnje da je ovdje riječ o pitanjima novih konstelacija odnosa između jezika i događaja. Uostalom, jedan od temeljnih problema suvremene filozofije nakon tzv. postmetafizičkoga obrata postao je problem jezika, kako je to ispravno uočio Habermas u svojoj 
knjizi. ${ }^{26}$ No, ovdje treba dodati da je pitanje jezika nemoguće razumjeti bez uvida u pokušaj promišljanja temeljnog filozofijskog pojma druge polovine 20. stoljeća. Posrijedi je pojam događaja (Ereignis) u Heideggera, te u francuskome poststrukturalizmu i neomarksizmu od Derridaa, Deleuzea i Lyotarda do Badioua. Da je tomu tako, uvjerljivo svjedoči i razmatranje koje poduzima njemački filozof i estetičar Wolfgang Welsch u svojim utjecajnim studijima, osobito u knjizi Naša postmoderna moderna (Unsere postmoderne Moderne) iz 1993. godine. U njoj tvrdi da se Lyotardovo mišljenje razotkriva kao korak spram napuštanja »antropocentrizma«. Razlog leži u tome što se događanje u jeziku ne može objasniti nikakvom subjektno-centričnom pozicijom. Umjesto toga, susrećemo se s nesvodljivom logikom razlika i heterogenosti koje su nesumjerljive. ${ }^{27}$

Ako se, dakle, jezik kao formalno uzevši komunikacijska struktura ljudskoga bitka ne može više smatrati uvjetom mogućnosti određenja biti čovjeka, nalazimo se na putu koji su ucrtali Nietzsche i Heidegger, a upravo su rezultati suvremenih tehnoznanosti potvrda ove postavke koja u krajnjem slučaju upućuje na »kraj čovjeka« i ulazak u doba čistih kontingencija. Svemu unatoč, Lyotard nije kao njegovi francuski suputnici u mišljenju (Derrida, Foucault, Stiegler, Nancy, Lacoue-Labarthe) bio posve u bliskome dijalogu s Heideggerom. Nije, naposljetku, u svojoj najvažnijoj filozofijskoj knjizi naslovljenoj Raskol s obzirom na pitanja odnosa estetike i politike posegao za pojmom događaja u Heideggera, već se zaputio iznova Kantu i njegovom pojmu uzvišenoga (Erhabenheit) iz Kritike moći suđenja, da bi dospio do formulacije o »prikazivoj neprikazivosti« koja odgovara čitavoj programatskoj estetici postmoderne u doba vladavine tehnoznanosti i digitalne simulacije. No, ono što je posve drukčije od Heideggera, Derridaa i Vatima nije, dakle, uporaba njemačkoga pojma prebolijevanje (Verwindung) metafizike. Umjesto njega, Lyotard već u programatskoj knjizi postmodernoga obrata, zacijelo ključnoj za sve što će se s postmodernom kasnije dešavati na teorijskome i praktičnome planu (etika, estetika, politika), na tragu kasnoga Wittgensteina uvodi svoj vlastiti pojam za jezične igre (Sprachspiele, language games). U doba heterogenosti i nesumjerljivosti, određenog vladavinom pluralnosti i agonalnosti u društvu, politici i kulturi, jedini način kojim se u svijetu bez prisile pseudo-totaliteta hegelovskoga tipa, ali i onoga što je postavkom kako istina nije cjelina zagovarao Adorno s njegovim pojmom estetske autonomije

20

Quentin Meillassoux, After Finitude. An Essay on the Necessity of Contingency, prev. Ray Brassier, Continuum, London 2010.

21

J. Derrida, De la grammatologie, str. 19.

22

Gianni Vattimo, La fine della modernità, Garzanti, Milano 1985.

23

Catherine Malabou, Le Change Heidegger: Du fantastique en philosophie, Léo Scher, Pariz 2004.

24

Martin Heidegger, Was heißt Denken?, u: Martin Heidegger, Gesamtausgabe, sv. 8, Vittorio Klostermann, Frankfurt na Majni 2002.
25

Usp. Ž. Paić, Postmoderna igra svijeta; Ž. Paić, »Politika estetskoga obrata: Lyotardovo mišljenje između projekta i programa«, u: Žarko Paić, Treća zemlja. Tehnosfera i umjetnost, Litteris, Zagreb 2014., str. 261-302.

26

Jürgen Habermas, Nachmetaphysisches Denken. Philosophische Aufsätze, Suhrkamp, Frankfurt na Majni 1992.

27

Wolfgang Welsch, Unsere postmoderne Moderne, Akademie Verlag, Berlin 1997. 
»subjekta«, može nastaviti živjeti u složenim sustavima zapadne demokracije pokazuje se u »postmodernome nominalizmu« znanja kao moći-činjenja (savoir-faire). Što je »smisao« jezika i događaja u okružju postindustrijskoga društva i postmoderne kulture?

Za Lyotarda je to know-how. Možemo ga nazvati konceptualni hologram. Njime se jezik ne izvodi iz transcendentalne strukture neke »velike priče« filozofije na zalasku (Hegel, Marx, Husserl, Heidegger, Freud). Umjesto toga, jezik označava događaj kontingentne borbe čovjeka sa svijetom kao mnoštvom događaja koji su međusobno nesumjerljivi. ${ }^{28}$ Nije teško zapaziti da je Lyotard s uvođenjem pojma postmoderno stanje (la condition postmoderne) doveo u svezu jezik i događaj kao komunikaciju. Za razliku od univerzalne racionalnosti diskursa u demokratskome dijalogu, ne oslanja se komunikacija više na pojam istine kao nečega što je unaprijed zadano i postavljeno nalik Kantovu rigorizmu prava i dužnosti građanina u kozmopolitskome poretku svijeta. Umjesto tog glavnog potpornja čitave zgrade kantovskoga i habermasovskoga konstitucionalizma i konstrukcionizma »uma«, na djelu je polimorfija i policentričnost interesa. Jasno je, pritom, da je partikularnost poduprta logikom razlika i da ono što prethodi univerzalnosti u logici, etici i politici ima značajke nesvodljivosti kvazi-temelja. Drugim riječima, na osnovu sinkretizma kasnoga Wittgensteina i osebujne preradbe Nietzschea i Heideggera $\mathrm{u} »$ postmoderne svrhe«, Lyotard je dospio do ključne postavke o bitku i vremenu nakon kraja metafizike u kibernetici. Što je to - postmoderno stanje? Posrijedi je vremensko određenje onoga što obuhvaća u sebi zatvorenu-otvorenost mogućnosti promjene. To nije puka aktualnost ni prolaznost, već uspostavljeni poredak u kojem smisao više nije nešto hermeneutički postojano i trajno, kao što je to još bilo u modernosti s njezinim kultom inovacije i originalnosti. Umjesto toga, na djelu je kontekstualno značenje neke situacije u sklopu odnosa. Budući da »bitak « postaje »informacijom « te u postmodernome stanju čovjek komunicira s Drugim medijalno, to znači da se mijenja i ono što je jeziku, s pomoću sustava znakova, određivalo uporabnu vrijednost. Jezik kao savoir-faire postaje konceptualni alat. Time služi za razumijevanje kontingentnoga događaja. Stanje, pak, za razliku od situacije i konteksta ima skriveni primat onoga što je blisko modalnim kategorijama zbilje i nužnosti.

Razlog valja pronaći u promijenjenoj biti znanosti u postindustrijskome društvu. Sada su to tehnoznanstveni protokoli konstrukcije »novih svjetova« s pomoću kompjutorske simulacije. Uostalom, sam je Lyotard 1985. organizirao izložbu naslovljenu Nematerijalno (Les Immatériaux) u centru Pompidou u Parizu. Postavio je instalacije s laserskom tehnologijom kao uvjetom mogućnosti nastanka nove »postmoderne estetike« s ključnim preokrenutim kantovskim pojmom »prikazive neprikazovsti« onoga što se naziva sublimnim objektom opažaja i razumijevanja bitka uopće. ${ }^{29}$ Ovim konceptualnim činom »postavljanja« onoga što ima karakter uzvišenoga bez odnosa s prirodom i ljudskim duhom ulazimo u prostor-bez-čovjeka. Neljudsko nije tek tehnologijska simulacija događaja. Naprotiv, ono što se pokazuje neljudsko kao takvo »jest« događaj prikazive neprikazivosti sklopa snaga koje više nisu određene kauzalno-teleologijski. Kao i Derrida i Deleuze, tako i Lyotard jasno uviđa da su mogućnosti vizualizacije »života $u$ u rukama tehnoznanstvenoga prodora $u$ samu »bit« njegova stvaranja.

Ipak, Lyotardov konceptualni hologram ne bi bio djelotvoran bez uvođenja pojma performativnosti jezika kao takvog. To je bilo posebno značajno stoga, što izvedbena značajka jezika u okružju tehnoznanstvene konstrukcije svje- 
tova pokazuje kako se komunikacija, u postmodernome stanju, više ne može razumjeti društveno ili kulturalno, u smislu samodjelatnosti ljudskoga duha neovisno o mediju komunikacije i stadiju razvitka tehnologijskoga aparata. Lyotard je posebno u spisu Neljudsko razradio postavku da tehnoznanosti govore jezikom aplikacije i izvedbenosti. Nije teško otuda zaključiti da je svaka apologija subjekta i voljno-smislene djelatnosti promjene stanja polazeći od aktivizma političke promjene ono što bi se moglo nazvati dječjim bolestima ljevičarski shvaćenoga aktivizma. Komunikacija u postmoderni postaje posthumano stanje čudovišno neljudske komunikacije. Nema sumnje da je Lyotard u razgovoru s astrofizičarima, kozmolozima i kibernetičkim stručnjacima, što je posvjedočeno u uvodnome tekstu zbirke Neljudsko naslovljenim »Može li biti mišljenja bez tijela?« (»Si l'on peut penser sans corps?«), postao svjestan da su mogućnosti onog ljudskoga-odveć-ljudskoga sve više i više sužene u našem suvremenom svijetu, odnosno da su već programski jezici i aplikacije svojevrsna vladavina programa i kodova nad neposrednom ljudskom spontanošću. ${ }^{30}$

U tom je pogledu njegov koncept »jezičnih igara«, preuzet od Wittgensteina u ono što nazivam tehnosferom, sveza performativnosti jezika i događaja. Obilježava ga, pritom, moment neodređenosti. Najvažnija posljedica koja otuda slijedi za postmoderni način tvorbe znanosti jest to što znanje postaje praktično umijeće i način uporabe $\mathrm{u}$ društvenoj situaciji s ciljem njezine promjene. To je pravo značenje savoir-fairea. Praktičnost i performativnost u načelu postaju vizualizirani pojmovi jer jezik ne može više biti sredstvo-svrha ove čudovišne neljudske komunikacije između razvijenih sustava i inherentnih svjetova života u okolini (korporacije - država - sveučilišta). Iz semiotike novih medija bjelodano je kako pragmatička razina komunikacije ima prednost pred sintaktičkom i semantičkom. ${ }^{31}$ Kako, međutim, Lyotard dolazi do posre-

28

Lyotard primjenjuje univerzalnu filozofijsku gramatiku kasnoga Wittgensteina za objašnjenje činjenica pragmatičkoga znanja suvremenih tehnoznanosti. To je metoda jezičnih igara. Za Wittgensteina se sve ono metafizič ko zbiva samo u gramatici jezika sukladnošću između misli i zbilje. Lyotard uzima od Wittgensteina koncept jezičnih igara na sljedeći način. Polazeći u analizi jezika od nule, cilj je pokazati učinke raznolikih diskursa s pomoću raznih vrsta iskaza. Svaka od kategorija iskaza određena je na temelju pravila iskaza koja su posebna po svojim svojstvima i mogu imati primjenjivost samo u određenom kontekstu u kojemu se takav iskaz rabi. Kao što se igra šaha određuje skupom pravila koja svakoj figuri podaruje njihovu ulogu u igri, tako se $\mathrm{i}$ jezičnom igrom određuje skup pravila unutar kojeg neki iskaz ima ili nema značenje i upućuje na smisao konteksta u kojem se događa igra. Lyotard, stoga, jezične igre shvaća na tri razine: (1) njihova pravila nemaju u sebi samima legitimnost, već su predmet izričitog ili neizričitoga ugovora među igračima; (2) bez pravila nema ni igre, a svaka promjena pravila mijenja bit igre, što uključuje da samo jedan "potez« ili iskaz suprotan pravilima ne pripada igri koja je njima definirana; (3) svaki iskaz valja gledati kao »potez« u nekoj igri. - J.-F Lyotard, La condition postmoderne, str. 1720; usp. Ludwig Wittgenstein, Philosophische Grammatik, Suhrkamp, Frankfurt na Majni 1978. Vidi o tome: Žarko Paić, »Jezik kao tehnosfera: Od 'forme života' do 'funkcije stvari' «, u: Ž. Paić, Tehnosfera, sv. II, »Crna kutija« metafizike: Kibernetika $i$ apsolutno vrijeme stroja, str. 173-219.

29

Više o tome: Antonia Wunderlich, Der Philosoph im Museum. Die Ausstellung »Les Immatériaux« von Jean-François Lyotard, Transcript, Bielefeld 2008.; Jean-Louis Déotte, »Les Immatériaux de Lyotard (1985). Un programme figural«, Appareil 5 (2012) 2, br. 10, str. 1-11, doi: https://doi. org/10.4000/appareil.797.

30

J.-F. Lyotard, L'inhumaine, str. 17-32.

31

Lev Manovich, The Language of New Media, The MIT Press, Cambridge (MA) - London 2001. Vidi o tome: Žarko Paić, Vizualne komunikacije. Uvod, Centar za vizualne studije, Zagreb 2008., str. 145-226. 
dovanja između svjetova - kantovski govoreći noumenalnoga i pojavnoga? Je li za tako nešto dostatno upozoriti na to da ako nema ni istine ni cjeline, da ako pritom više nije od pomoći ni bilo kakva vjera u »velike priče« metafizike od Platona do Hegela i dalje, da tada moramo krenuti od čistog slučaja događaja koji su heterogeni i nesumjerljivi i pokušati ih ostaviti nedodirljivim u mogućoj sintezi razlika?

Problem je, dakako, u tome što svaka ontologija pretpostavlja vremensku strukturu bitka kao vječnosti, trajnosti, nepromjenljivosti. Da bi komunikacija u nihilistički raspadnutome svijetu kaosa i entropije uopće imala izglede za ozbiljenje na temelju priznanja razlika u onome što pripada »ljudskome«, nužno je umjesto logike i etike-politike postaviti u središte najkrhkiju biljku suvremenosti bez koje ništa više ne cvjeta. To je, samorazumljivo, estetika i ono estetsko kao uvjet mogućnosti svake logike djelovanja. Za Lyotarda je tvorba postmodernoga stanja kao posthumanoga stanja nešto u sebi istodobno nepojmljivo i neodređeno, kao što je to i područje ljudske osjetilnosti s misterijem tjelesnosti s onu stranu uma i jezika metafizike. ${ }^{32}$ Prema tome, prolazak kroz tri stadija misaonoga susreta postmodernoga obrata i posthumanoga stanja, kako sam to već prije izložio, odvija se kroz: (a) osjećaj uzvišene moći tehnosfere, (b) želju za raskolom unutar moći kapitala koji više ne djeluje kao otuđena stvar, već kao postvareni sublimni objekt želje i (c) konstrukciju stroja u tehnoznanstvenoj proizvodnji umjetnoga života (A-life). U nastavku ću iznijeti sljedeće »novo« tumačenje.

\section{Mistika estetskoga obrata}

Lyotardova postmoderna estetika oslanja se izričito na drukčije razumijevanje Kantova pojma uzvišenosti. No, to nije uzvišeno unutar kruga ljepote kao svrhovitosti bez svrhe. Posrijedi je ono otvoreno i dinamičko pomoću kojih se mogu razumjeti paradoksi i aporije avangardne umjetnosti. Ako je aksiom svake postmoderne filozofije kraj metafizike i ulazak u razdoblje programiranoga kaosa i entropije, onda je ono što preostaje tom stanju stvari koje pokriva pojam postmoderne svedenost na jezik i događaj. Jezik postaje know-how, dakle, pragmatika znanja na kakvom danas počiva logika djelovanja svih novih medija. Tome usuprot, događaj (événement) događa se izvan horizonta u kojem metafizika postavlja bitak u prisutnosti (ousia). Svaka estetika uzvišenoga nužno mora postati negativna estetika iz jednostavnog razloga što pojam negacije predstavlja jedino sredstvo avangardnoga samouspostavljanja »novoga« u svijetu. Evo odgovora na pitanje - što je to postmoderna:

»Što je, dakle, postmoderna? Koje mjesto zauzima ili ne zauzima u vrtoglavu nizu pitanja upućenih pravilima slike ili pripovijetke? Zasigurno je dijelom moderne. Sve što je naslijeđeno pa bilo i od jučer (modo, modo, pisao je Petronije) moramo dovesti u sumnju. Kojemu prostoru ne vjeruje Cézanne? Onom impresionista. Koji objekt osporavaju Picasso i Braque? Onaj Cézanneov. S kojim pretpostavkama prekida Duchamp 1912.? S onima da slikar mora slikati sliku pa bila ona i kubistička. A Buren dovodi u pitanje onu drugu pretpostavku za koju drži da je netaknuta izašla iz Duchampova djela: mjesto prezentacije djela. Začuđujuće ubrzanje, 'generacije' preskaču jedna drugu. Djelo ne može postati moderno ako prvo nije bilo postmoderno. Tako shvaćen postmodernizam nije modernizam na svome koncu nego u stanju nastanka, a to je stanje konstantno. $\ll^{33}$

Zašto Lyotardu uopće treba povratak Kantu? Naposljetku, čemu uopće posezati za drugim temeljnim pojmom klasične estetike ako ne zbog uvida da je ono što Schelling, Heidegger i Freud nazivaju Unheimliche (čudovišno, 
jezovito, strahotno, bezavičajno) sama bit našeg svijeta tehnoznanstvenih konstrukcija. U nemogućnosti pomirenja zahtjeva razuma i uma s estetskim doživljajem čiste osjetilnosti, što još preostaje? Raskol ili raspor, disimulacija, distancija između zahtjeva mišljenja kao računanja, planiranja i konstrukcije te mišljenja kao ne-konceptualne noeme ili monograma. ${ }^{34}$ Što smo time dobili? Samo ovo: kada nema reza između istog u razlikama, što znači da postmoderna nema vremenski karakter epohe, već je riječ o stanju, vrijeme postaje temeljni problem ne samo suvremene umjetnosti. Štoviše, vrijeme postaje misterij suvremene filozofije i kozmologije utoliko što sada više ne možemo kao Heidegger govoriti o nadolazećem događaju mogućnosti »drugoga početka« bitka kao onog spasonosnoga, nego moguće još o događaju nesvodljiva otpora mišljenja svemu neljudskome što ugrožava svijet kao takav. U tom svjetlu ima nešto uistinu više negoli paradoksalno. Sa stajališta "pravovjernosti« tumačenja zagonetke smisla teksta najvećim su dijelom sva postmoderna tumačenja Kanta, Nietzschea i Heideggera u odnosu na hermeneutičku »doslovnost « često na rubu poprilično slobodnih asocijacija.

Dostatno je za to sučeliti Gadamerovo tumačenje Platona i Hegela s istim nastojanjima Derridaa. Zbog toga se i događa kadšto da se i Lyotardovo tumačenje Kanta ne smatra najvišim dosegom istraživanja problema uzvišenoga. Međutim, sve to nije uopće odlučujuće za bit postmodernoga obrata. Time ne želim reći da je posrijedi konfuzija i pad ispod razine, kako ponekad možemo čitati u različitih mahom njemačkih novijih tumača filozofijske tradicije koji gotovo posprdno navode i taj tzv. postmoderni pristup čitanju teksta kao

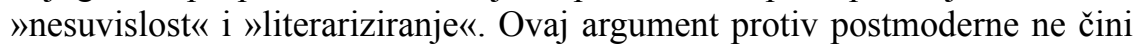
mi se »suvisao«. Više je to izlika za vlastitu stvaralačku nemoć, negoli razlog za plodotvornu kritiku. Prigovor, pak, o »literariziranju « još je promašeniji. Zar je jezik kazivanja Nietzschea, primjerice, zreo za »znanstveni objektivizam«!? Time je unaprijed dostojanstvo estetskoga mišljenja srozano na dosadno raspredanje pukog historiografskog karaktera. Dostatno je navesti neki Nietzscheov aforizam iz raznih spisa, od Rođenja tragedije do Volje za moć u kojima bespoštedno pokazuje kako znanstvenost obogaljuje život, ali na drukčiji način od onoga što čini religioznost. Oba su pristupa bitku, znanstveni i religiozni, posvemašnja redukcija smisla bitka kao »života« na sklop vrijednosti bez životnosti samoga života. Pristup tumačenju teksta, zaslugom ponajprije Derridaove dekonstrukcije, ustanovio je u suvremenoj filozofiji potrebu za razumijevanjem onoga što pripada prošlosti i ne može se nikakvim udahnućem novoga života osuvremeniti. Isto tako, ono što je živo u svojoj veličini poput, primjerice, kasnoantičkoga shvaćanja pojma parezije i Sokratove »brige za dušu«, na navlastit su način u svoje mišljenje inkorporirali Michel Foucault i Jan Patočka. ${ }^{35}$ Možemo naći još podosta sličnih primjera. Svi su oni u službi postavke da je tumačenje tradicije u suvremenosti ponaj-

32

Vidi o tome: James Williams, Lyotard and the Political, Routledge, London - New York 2000.; Peter Zima, Asthetische Negation. Das Subjekt, das Schöne und das Erhabene von Mallarmé und Valéry und Lyotard, Königshausen \& Neumann, Würzburg 2005.

33

Jean-François Lyotard, »Odgovor na pitanje: što je postmoderna?«, u: Jean-François Lyotard, Postmoderna protumačena djeci, prev. Ksenija Jančin, August Cesarec, Zagreb 1990., str. 25-26.

34

J.-F. Lyotard, L’inhumaine, str. 15.

35

Michel Foucault, Vladanje sobom i drugima. Predavanja na Collège de France (19821983), prev. Zlatko Wurzberg, Izdanja Antibarbarus, Zagreb 2010.; Jan Patočka, Plato 
prije stvaralački čin gotovo nalik prevođenju poezije. Nije važna dogmatska odanost »duhu izvornika« ako mišljenje nastalo u dalekoj ili bližoj prošlosti više ništa bitno ne govori suvremenicima.

Kada estetska dimenzija »života« uvjetuje nastanak novih etičko-političkih zahtjeva za pohvalom razlika i partikularnosti kultura, nužno je vidjeti je li još uopće pojam nihilizma kao obezvređivanja svih vrijednosti primjeren okvir mišljenja povijesti koje više nema smisla, ali ima čitav horizont novih kontingentnih značenja. Lyotard je trebao Kanta, što je uistinu aporetično i paradoksalno za postmoderni obrat, samo zbog toga što mu je u analogiji s novovjekovnom subjektivnošću nedostajao razoreni pojam namjesnika i izvršitelja konstrukcije svijeta kao pomirenja teorije, prakse i proizvodnje. I doista, nije li uz sve druge poteškoće s kojima se susrela postmoderna upravo problem samoodređenja »subjekta« ono što izaziva neprestane sporove i razračunavanja? Tko je uopće »subjekt« ovog nihilistički određenoga »kraja povijesti« ako ne ničeansko-hajdegerijanski filozof-kao-umjetnik koji nadilazi neljudsko estetskom konstrukcijom »života« s onu stranu dobra i zla?

\section{Kraj subjekta: stanje i događaj}

Wolfgang Welsch u tumačenju Lyotardova odnosa između jezika i događaja lijepo kaže da »čovjek nije gospodar jezika, već je jezik strukturalno i događajno prethodeći, te čovjek ulazi u jedino od jezika otvorenu igru«. ${ }^{36} \mathrm{Mo}-$ žemo nešto slično pronaći i kod Lacana kada kaže da »čovjek nije gospodar u svojoj kući« ${ }^{37} \mathrm{U}$ oba slučaja jezik ima značajke događaja prethodećega pojmu samosvjesnoga subjekta. Što to znači? Nesumnjivo, mnogi su francuski filozofi, pa i psihoanalitičar Lacan, svoje postavke o kritici humanizma i »kraju čovjeka« izvodili osim na zasadama Nietzschea, Heideggera i Freuda i na nezaobilaznoj semiologijskoj ili semiotičkoj teoriji jezika Ferdinanda de Saussurea, pragmatičkoj filozofiji Charlesa S. Piercea i lingvistici Louisa T. Hjelmsleva. Tako i Lyotard u svojoj kritici jezika polazi od istih premisa kao i kasni Heidegger kada tvrdi da jezik govori, a nije u službi informacije-komunikacije. ${ }^{38} \mathrm{Je}$ li onda jezik u postmodernome obratu već na putu da postane »novi« događaj mišljenja s onu stranu performativnosti tehnoznanosti koja od jezika treba samo uputstva za izvedbu i ništa drugo?

Ne možemo razumjeti svijet ako nam je jezik nemušt, ako ga vode neki drugi ciljevi izvan njegove veličajne metafizičke biti kazivanja. Kako god bilo, glavni mislioc postmodernoga obrata kao što je to Lyotard nije od jezika stvorio događaj u smislu lingvističkoga čina stvaranja novih značenja. Uzevši Wittgensteinov pojam jezičnih igara iz njegova kasnoga razdoblja mišljenja za temelj razumijevanja statusa pojma znanja i znanosti u postindustrijskome društvu te ga usmjerivši u svojevrsni alat za proizvodnju događaja kao što su to etičko-političke i kulturalne igre oko moći, postalo je izvjesno da je sam »subjekt« ovog jezičnoga događaja gotovo isto što i pojam performativnosti za suvremenu umjetnost. Naime, izvedba jezika jest događaj konstrukcije "novoga subjekta«. No, nije to više nikakav veliki ili mali »subjekt«, onaj koji se znamenuje kao duh, rad, svijest, moć. Umjesto toga, otvorio je Lyotard prostor za promišljanje konstelacije snaga u odnosima među mnoštvom različitih »subjekata«. To nisu nikakve habermasovske »idealne govorne situacije« jer je univerzalnost uma postala fikcijom još od Nietzschea. Pravi je problem ono što proizlazi iz heteromorfije savoir-faire i pluralne agonistike na jedinom mjestu kvazi-univerzalnosti. A to može biti samo institucija tržišta 
u informacijskom kapitalizmu sprege želje i objekta moći. Drugim riječima, jezik više nije uvjet mogućnosti komunikacije u postmodernome kontekstu partikularnosti (kultura). »Subjekt« je na taj način ostao bez svoje »supstancije« jer je bit jezika, kao što tvrde semiotičke teorije, izvan jezika - u sustavu znakova bez transcendentalno određenoga označitelja. ${ }^{39}$

Što je, dakle, »subjekt« u okviru onoga što Lyotard naziva postmoderno stanje? Odgovor nije izričito podastrijet u glavnomu njegovu djelu Postmoderno stanje, iako se naslućuje kamo smjera ovo mišljenje, nego u spisu Neljudsko. Nismo slučajno pitanje postavili ontologijski, pitajući o »štostvu« (quidditas) nekog bića kao bića. Ako je već s Lacanom postalo jasno da antihumanizam određuje pristup »čovjeku« i njegovim traumama jer se nesvjesno artikulira kao jezik, onda u postmoderni, kako je opisuje Lyotard, taj i takav »subjekt « biva određen mnoštvom »jezičnih igara« od znanosti, politike, prava, etike, kulture, umjetnosti. Mišljenje se oslobađa čitavog nasljeđa metafizike subjektivnosti, uključujući i ono ključno mjesto posredovanja između bitka i vremena koje se događa u jeziku kao artikulaciji uma i samosvijesti. Uostalom, poststrukturalizam je u svim svojim formama kritika objektivizma $\mathrm{i}$ subjektivizma jezika kao kriterija spoznaje. Tek jezik koji više ne iskazuje, već pokazuje i ukazuje na događaje u nekom određenom (društveno-kulturalnome) kontekstu može biti svjedokom »konsenzualne agonistike«. Da bi, dakle, »subjekt« imao svoje opravdanje mora se emancipirati od »prirode« kao metafizičkoga označitelja. Jezik više nema svoj svijet kao što svijest više nema svoj jasan i pouzdan intencionalan predmet. Stoga je po prvi puta u čitavoj ljudskoj povijesti jezik postao mrežom »lakih označitelja«, strukturom bez strukturalnosti, »subjektom « bez supstancije. I kao što svi poststrukturalisti polaze od ideje da kraj subjekta svijesti istovremeno označava početak mišljenja jezika, tako se aporija i paradoks ovog obrata sastoji u tome što ono neljudsko određuje ljudsku egzistenciju i daje joj smjer za nadolazeće doba.

Čitajući Lyotarda kao vodećeg mislioca postmodernoga obrata vidimo nešto što je konstanta za sve pokušaje u filozofiji, sociologiji, teoriji arhitekture, vizualnoj umjetnosti, književnosti, glazbi i plesu. Posrijedi je nužan i često iznimno problematičan »eklekticizam《i »sinkretizam« mišljenja. Možda je to najrazvidnije u slučaju Gillesa Deleuzea, koji je u svoje mišljenje uključio čitav niz diskurzivnih strategija filozofije Spinoze, Nietzschea, Kierkegaarda, Bergsona, Whiteheada i Simondona. Sve mu to nije nimalo naškodilo. Naprotiv, mislim da je njegovo »transverzalno mišljenje« iznimno podobno za razumijevanje tehnosfere jer je sve metafizičke kategorije i pojmove ne samo rastemeljio nego je i zajedno s Félixom Guattarijem stvorio novu metafiziku

and Europe, prev. Petr Lom, Stanford University Press, Stanford (CA) 2002.

36

W. Welsch, Unsere postmoderne Moderne, str. 249.

37

Jacques Lacan, The Seminar of Jacques Lacan. Book II: The Ego in Freud's Theory and in the Technique of Psychoanalysis, 19541955, prev. Sylvana Tomaselli, W. W. Norton \& Company, New York 1991., str. 307. Vidi o tome: Žarko Paić, »The New Theory of Subject«, u: Ž. Paić, White Holes, str. 39-105.
38

Martin Heidegger, Unterwegs zur Sprache, $\mathrm{u}$ : Martin Heidegger, Gesamtausgabe, sv 12, Vittorio Klostermann, Frankfurt na Majni 2018 .

39

Vidi o tome: Dieter Mersch, »Das Entgegenkommende und das Verspätete Zwei Weisen das Ereignis zu denken: Lyotard und Derrida«, u: Dieter Mersch, Posthermeneutik, Akademie Verlag, Berlin 2010. 
postajanja ili bivanja (devenir), koja u dijalogu s umjetnošću i znanošću niti gubi filozofijsko dostojanstvo, niti se može smatrati anakronim pristupom složenosti suvremenoga svijeta. ${ }^{40}$ No, kada je riječ o Lyotardu, tada se nalazimo u sporu s nasljeđem Hegela i Marxa, Freuda i Adorna, odnosno kritičke teorije društva. Postmoderni obrat nije, dakle, tek analiza i kritika društveno-kulturalnih uvjeta proizvodnje života u informacijskome kapitalizmu koji je postao autopoietički sustav onoga neljudskoga jer počiva na realizaciji želje za vladavinom strojeva u formi »umjetne inteligencije« (A-intelligence). Miješanje i prisvajanje misaonih poticaja iz mnoštva izvora čini se da je za naše doba nešto samorazumljivo. Sve to, naravno, ima svoje podrijetlo u Nietzschea. Njegova dijagnostika i terapeutika europskoga nihilizma polazi od toga da ne postoje nikakve univerzalne vrijednosti, a »istina« se ne može smatrati nikakvom objektivnom zbiljom prema modelu srednjovjekovne teologije i sv. Tome Akvinskoga u iskazu adequatio intellectus et rei.

Ako nema razloga za postojanje univerzalnih vrijednosti, onda se mora osloboditi prostor za čitav niz diskurzivnih figura mišljenja. U ranome djelu koje tematizira upravo problem nastanka »slike mišljenja«, Lyotard upućuje na zaokret od svakovrsnog objektivizma i želje za razumijevanjem zbiljskoga stanja s pomoću okoštalih pojmova zapadnjačke metafizike. Izlaz je jedino u miješanju diskursa, u spoju nespojivoga, u radosnome sinkretizmu stilova kakvo je 20. stoljeće uistinu i bilo u potpunosti, od dekadencije do avangarde, od povratka ornamenta do radikalnoga ikonoklazma. ${ }^{41}$ Doista, u toj mistici estetskoga obrata čini se da politika razlike i višeznačnosti onoga što pripada području neodređenosti »uzvišenoga« obilježavaju sve daljnje sporove između postmoderne i modernosti kao jednako tako neodređenoga pojma, osim njegove utemeljenosti u onome što Adorno naziva autonomnom sferom ljudske slobode stvaralaštva. Da je tomu tako, možemo se uvjeriti već time što, osim Habermasa, mnogi suvremeni teoretičari nastoje oko »neomoderne«, »hipermoderne«, različitih rekonstrukcija pojma u želji da razumiju što se događa s »društvom《 kada u globaliziranim procesima ekonomije, politike i kulture ono postaje »zombi kategorijom«, kako je to samokritički i cinično rekao jednom Ulrich Beck, sociolog »refleksivne modernizacije $\ll .{ }^{42}$ Ukratko: spor Lyotarda i Habermasa, postmoderne i moderne, bio je nužan i koristan za pročišćenje prostora za ono jedino što je bitno. Reći da je Habermas "promašio« cilj svoje kritike nastojanjem na obrani nasljeđa Kanta i Adorna protiv ove »konzervativne mistike iskona«, kako je nespretno nazvao čitavu struju mislioca »francuske postmoderne« (Derridaa, Deleuzea, Foucaulta, Bataillea, Lyotarda, pa čak i Castoriadisa koji ne pripada krugu ovog mišljenja), nije toliko važno koliko je dokaz da je spor bio istog ranga kao i spor o dva lica boga Janusa s obzirom na problem kraja metafizike u znanstveno-tehničko doba. Nije postmoderni obrat ni u svojim najvećim misaonim dosezima kao u Derridaa, Deleuzea i Lyotarda ništa drugo negoli očigledna nelagoda u razmatranju odnosa između jezika i događaja, slike i tehnosfere, jer je sve što je preostalo od postmoderne upisano u novi lik nihilizma koji je izričito pokazao upravo Lyotard u spisu Neljudsko. Na pitanje podnaslova ovog razmatranja, što je preostalo od postmoderne, možemo unaprijed odgovoriti na sljedeći način. Preostalo je samo ono što je nastavak postmodernoga stanja drugim sredstvima - posthumano stanje. Ako je takvo »stanje « (condition) ono koje više nema ni svojeg »subjekta«, ni »supstanciju« u tradicionalnome metafizičkome određenju bitka, biti čovjeka i bića u cjelini, kako ga treba razumjeti i s kojim diskurzivnim figurama mišljenja? Je li još moguće rabiti pojmove koji su izgubili svoje značenje i smislenost $u$ doba bez metafizičkoga patosa 
povijesti ako se susrećemo s temeljnim pitanjem koje je Lyotard krajnje jednostavno postavio i time usmjerio filozofijsku raspravu prema pravom cilju: Može li biti mišljenja bez tijela?

\section{Neljudsko kao tehnosfera}

Zašto mislim da su analize filozofijskoga pojma postmoderne, unatoč neporecivoj pojmovne nezgrapnosti i proturječnosti, daleko od toga da se mogu jedino svesti na ono što uobičajeno izvode u svojim analizama tzv. kulturalni teoretičari:

(1) kritiku modernosti i njezine vjere u bezuvjetni »napredak«;

(2) političku pluralnost i liberalni multikulturalizam;

(3) zagovor eklektičke popularne kulture i povratka ornamenta u arhitekturi;

(4) pohvalu razlika, mnoštva, Drugoga kao etičko-političkoga obrata, osobito u pristupu Lévinasa i Derridaa, ${ }^{43}$

(5) napuštanje avangardne »isključivosti« i zagovor neoavangardne subverzije društva;

(6) kulturalnu logiku kasnoga kapitalizma u pristupu Fredrica Jamesona. $^{44}$

Odgovor je sljedeći. Budući da je postmoderna dobila svoje filozofijsko opravdanje u spisima Lyotarda, Vattima i Baudrillarda, te interpretativno u Welschovoj estetskoj teoriji, da navedemo najvažnije mislioce, a da se već koncem 1960-ih godina u dvije temeljne knjige poststrukturalizma, u Derridaovom djelu $O$ gramatologiji i Deleuzeovom djelu Razlika i ponavljanje nalaze vodeći pojmovi poput dekonstrukcije povijesti zapadnjačke metafizike i ontologije postajanja ili bivanja (devenir) s uvođenjem mnoštva, razlike, virtualnosti, simulakruma, tada valja pokazati da je ono najplodotvornije u ovoj »silaznoj putanji« nihilizma nesumnjivo pronalazak »rupa u mreži« svega onoga što je bilo još uvijek vezano uz dijalektiku Hegela i Marxa, s jedne strane, a s druge, uz fenomenologiju Husserla i frankfurtsku kritičku teoriju društva. Ove filozofijske orijentacije predstavljaju konceptualne zidove na kojima upisani tragovi kritike njihovih ishodišta određuju neodređenost postmoderne i njezinih »vrtova s razgranatim stazama«, da se poslužimo naslovom jedne zbirke Borgesovih pripovijesti. Stoga je potrebno u raspravi o postmoderni i njezinim »preostacima u u suvremenosti ponajprije učiniti jedan nužan metodički i spoznajni epoché: sve što je tijekom vremena postalo "postmoderno« očistiti od onoga što filozofijski ovaj sporan pojam ipak zaslužuje. Već smo

40

Gilles Deleuze, Félix Guattari, Mille plateaux. Capitalisme et schizophrénie 2, Éditions de Minuit, Pariz 1980.

41

Jean-François Lyotard, Discourse, Figure, prev. Antony Hudek - Mary Lydon, University of Minnesota Press, Minneapolis - London 2010.

42

Vidi o tome: Oliver Marchart, Das unmögliche Objekt. Eine postfundamentalistische
Theorie der Gesellschaft, Suhrkamp, Frankfurt na Majni 2013., str. 15-16.

43

Vidi o tome: Žarko Paić, Sloboda bez moći. Politika u mreži entropije, Bijeli val, Zagreb 2013., str. 346-432.

44

Fredric Jameson, Postmodernism. Or, Cultural Logic of Late Capitalism, Duke University Press, Durham 1992. 
istaknuli da je to, za razliku od onoga što tvrdi Vattimo govoreći o Heideggerovu prebolijevanju (Verwindung) metafizike, nešto bitno drukčije.

Ponovimo još jednom glavnu postavku: postmoderni obrat nakon »kraja metafizike« u kibernetici ne odnosi se uopće na Heideggerovo mišljenje nadolazećega događaja (Ereignis), već na primjenu jezičnih igara (Sprachspiele, language games) kasnoga Wittgensteina. Stoga, postmoderna u filozofiji ne može biti nikakvo spasonosno iščekivanje »drugoga početka« (der andere Anfang). Umjesto toga, njezino je ontologijsko određenje iskazano upravo riječju-pojmom koji rabi Lyotard u svojem programatskome spisu iz 1979. godine, napisanom prigodno za Sveučilišno vijeće pri vladi Quebeca. Ta riječ-pojam jest - stanje (condition). Dakle, postmoderna je u svojoj biti izravno povezana s onim što predstavlja najveći problem mišljenja uopće, a to je vrijeme u dimenziji »aktualnosti«. Razlika između »prebolijevanja« metafizike i savoir-faire jezičnih igara postmoderne (Heideggera i Wittgensteina) čini se da je razlogom zašto je put ovog neodredivoga obrata u mišljenju usmjeren logici kontingencije, pragmatici znanja, nastojanju da se naposljetku naspram nezadrživoga prodora tehnoznanstvenoga »uma« i njegove trijade računanja, planiranja i konstrukcije očuva prostor-i-vrijeme »estetskoga otpora«. Iz ovoga je razvidno da su sve politike postmoderne na ovaj ili onaj način upravo ono što Lyotard najavljuje u Postmodernome stanju - pokušaj preusmjeravanja liberalno-demokratske utopije o »kraju povijesti« u estetsku nesvodljivost slobode i pravednosti. Tzv. »male priče« (petits récits) postmoderne odnosno »meta-priče« (meta-récits) nisu, međutim, oproštaj od onoga što se i danas posve neuspješno želi obnoviti s tzv. neolakanovskim marksizmom (rad, klasna borba, komunizam), već njegovo posvemašnje suspendiranje i neutraliziranje kako zbog totalitarizma 20. stoljeća, tako još više zbog apsolutne moći onoga za što i Heidegger naposljetku više nije mogao naći izlaz iz metafizičkoga labirinta osim u nadi da spasonosno počiva u »biti« umjetnosti kao kazivanja. ${ }^{45}$ To na što Heidegger nije imao više pravog odgovora jest »mahnitost bez utjehe oslobođene tehnike« (»trostlosen Raserei der entfesselten Technik «). ${ }^{46}$

Pogledajmo ima li Lyotard kao temeljni mislilac postmodernoga obrata odgovor na to pitanje o pomahnitaloj tehnici koja se oslobodila svih ljudskih okova. Rekli smo već da je ono što preostaje od postmoderne realizirano drugim sredstvima u tzv. posthumanome stanju. U svojoj knjizi o tom problemu iscrpno sam se bavio ne samo Lyotardom i tumačenjem njegova spisa Neljudsko nego i posthumanizmom, transhumanizmom i estetikom, biopolitikom, društvima kontrole, Foucaultom, Agambenom, Artaudom, Deleuzeom, Derridaom i Batailleom. ${ }^{47} \mathrm{Za}$ ovo razmatranje nije primjereno sažimanje već izrečenih postavki koje su objašnjene ekstenzivno u sklopu promišljanja onoga što nazivam tehnosferom. Dostatno je samo podsjetiti na to da se Lyotardov glavni ogled »Može li biti mišljenja bez tijela? « na filozofijski jednostavan način suočava s pitanjem kibernetičke tjelesnosti, kraja čovjeka, umjetnom inteligencijom i procesima koje posthumanizam i transhumanizam još 1980-ih godina nazivaju kiborgiziranjem i tehnoznanstvenom konstrukcijom »umjetnoga života« (A-life). U svojem petoknjižju Tehnosfera posebnu sam pozornost posvetio analizi ontologijskih pretpostavki razumijevanja kibernetike i informacijske tehnologije u teorijskim pristupima Gilberta Simondona, koji je presudno utjecao na Gillesa Deleuzea, potom u trilogiji Bernarda Stieglera Tehnika i vrijeme te naposljetku u dijaloškome odnosu u razumijevanju ovog problema u radovima Heideggera i Deleuzea. Sve ovo spominjem radi 
toga što je bjelodano kako je u francuskome poststrukturalizmu promišljanje biti suvremene tehnologije možda čak i važnije od svih drugih dalekosežnih kritika politike, društva, kulture. Nije teško zaključiti da je postmoderna u tom smislu istodobno i filozofijsko-kulturalna analiza biti suvremenoga svijeta, polazeći od pitanja o granicama tehnnoznanstvene paradigme mišljenja. Lyotard je uistinu jezgrovito i precizno u navedenom uvodnome ogledu $\mathrm{Ne}$ ljudskoga iskazao ono što određuje spor između filozofije-umjetnosti i tehnoznanosti (technoscience).

Već je iz imenovanja ovog sklopa u kojem su spojeni tehnologija i znanost vidljivo nadilaženje granica moderne tehnike. ${ }^{48}$ Iako sam Lyotard kaže »da tehnika nije pronalazak čovjeka«, a taj iskaz upućuje na kritiku antropologizma kakvu je inače utemeljio Heidegger još iz doba Bitka i vremena, ovome je potrebno dodatno obrazloženje. Čovjek se ne poima subjektom koji u svojim rukama posjeduje ključ stvaranja »novoga«. Posrijedi je odnos između onoga što Grci nazivahu lógos i téchne pa je otuda samorazumljivo da se tehnika pojavljuje kao razotkrivanje mogućnosti koje bitak kao »priroda« (physis) već uvijek ima skrivene u samome sebi. No, ono što je ovdje najvažnije jest da Lyotard dobro zna da su tehnoznanosti realizacija onoga »neljudskoga«, a ne puki instrumenti ljudskoga uma unatoč svega što dobroga i korisnoga pridonose usavršavanju ljudske civilizacije. Za razliku od tehnike, tehnoznanost su konstrukcija onoga što nadilazi »bit« prirode kao takve. Razlika između preradbe "prirode« u svrhu njezina očuvanja bez iskorištavanja potencijala stvaranja-razaranja kao što je to bjelodano u okružju nuklearne fizike te tehnoznanstvenoga »proizvođenja« onoga što ima karakter nadilaženja granica »prirode« pokazuje da je čovjek shvaćen uvijek dvoznačno: kao namjesnik bitka i kao gospodar planetarno određenoga nihilizma.

Sve izrečeno bilo je Lyotardu razvidno i u okviru opisa postmodernoga stanja. Tamo je, naime, jasno uočena granica i razlika između humanističkih znanosti i prirodno-tehničkih koje postaju uvjet mogućnosti tehnoznanosti. Potonje se utemeljuju u performativno-aplikativnoj logici pragmatike znanja. To znači da je znanje kao savoir-faire (know-how) epohalna pobjeda pragmatičnoga učinka nad svim drugim formama znanja. Nije nipošto slučajno, pak, da je tzv. eficijentni uzrok (causa efficiens) najznačajniji u sustavu kibernetičke kontrole nad procesima upravljanja životom od njegova nastanka (gen + informacija) do kraja i prelaska u ponovljivu neponovljivost. Razlog leži u tome što je ovdje na djelu pragmatika koja proizlazi iz biti stroja, a pokreće ga kibernetički sustav informacija. Mehanička tehnologija još je uvijek u vlasti formalno-materijalnoga uzroka jer počiva na reprodukciji izvornika Digitalna tehnologija, tome usuprot, u sebi obuhvaća simulaciju, virtualnost i konstrukciju »događaja«.

Problem individuacije života za Lyotarda je još veći negoli za moderne prethodnike, primjerice Nietzschea i Marxa, jer se po prvi put u povijesti suočavamo s mogućnošću laboratorijske proizvodnje genetski promijenjenoga

45

Vidi o tome: J.-F. Lyotard, Postmoderna protumačena djeci, str. 58-102.

46

Martin Heidegger, Einführung in der Metaphysik, u: Martin Heidegger, Gesamtausgabe, sv. 40, Vittorio Klostermann, Frankfurt na Majni 1983., str. 28
47

Ž. Paić, Posthumano stanje.

48

J.-F. Lyotard, L'inhumaine, str. 20-21. 
bića. Biti na način ljudske egzistencije pretpostavlja individuiranje. No, za drukčije oblike prisutnosti »života« moguće je uspostaviti transindividuaciju, hibridne sveze i transmutacije organizma. Ono što je biološki »zadano« nije više tako u okružju tehnogeneze. Na taj se način postavlja pitanje mogu li humanističke znanosti, koje se još uvijek bave »čovjekom«, uopće preostati u doba posthumanoga stanja. Njihova predmetna područja isušuju se, preklapaju, nastaju i nestaju vrtoglavim ubrzanjem tehnosfere. Kada vizualiziranje događaja mijenja opažajne mogućnosti »subjekta«, jezici u svojem prirodnome stanju više ne mogu slijediti značenje onoga što postaje ili biva »novo«. Ako je povijest ostala »bez smisla« time što je u postmodernome obratu sve postalo nadomjestivo, razmjestivo, premjestivo, istodobno ništavno i potrošivo od informacije do mreža komunikacije koje su nadomjestile tzv. društvene odnose u kognitivnome kapitalizmu, onda je posve očekivano da će korporacije preuzeti kontrolu ovog procesa od tradicionalno shvaćene nacije-države. Dok, naime, država pretpostavlja tzv. realni teritorij vlastite izvedbe moći, korporativna je struktura svijeta u neoliberalnome kapitalizmu suvremenosti ona koja odgovara ideji-metafori mreže (network). Biti-umrežen znači biti »konektiran« s drugim akterima događaja, a to je zoran dokaz da su pojmovi društvo i subjekt izgubili svoje značenje. Sjetimo se svojevrsnoga proroštva Lyotarda u spisu Postmoderno stanje o ulozi sveučilišta, javnoga znanja i korporativnoga vlasništva nad znanjem kao robom na tržištu. Sve se već u potpunosti realiziralo u neoliberalnome kapitalizmu fluidnih mreža ljudsko-neljudskih transakcija među prirodom, društvom i kulturom. Tehnosfera $\mathrm{u}$ formi umjetne inteligencije suvereno upravlja životom i kontrolira ono što je još preostalo od čovjeka. Od autopoietičkih strojeva života do autonomnih objekata koji ubrzavaju operacije prijenosa i pohrane informacija, energije i materije sve smjera u singularnost kozmocentrične post-povijesti. Naposljetku, utopija je dovršena, a distopija u svim aspektima iskazuje kako je u posthumanome stanju proizvođenje života kontingentna »sudbina« na rubu kaosa i entropije. Što je uistinu ono najdublje što je Lyotard promislio u spisu Postmoderno stanje? Ništa drugo negoli ovo: tehnoznanstveni kôdovi ili modeli spoznaje realnosti praktično konstruiraju svijet koji sam po sebi uopće ne postoji. Ali umjesto transcendentalne svijesti kao legitimacije univerzalne ljudske povijesti, postmoderno je stanje određeno legitimacijom pragmatike znanja u poretku društvenoga samoorganiziranja odozdo. Svijest zamjenjuje poredak različitih jezičnih igara među kojima se u samo središte odlučivanja postavlja tehnoznanstveni diskurs. ${ }^{49}$

Što određuje ovu transformaciju znanja i znanosti u čudovišni sklop tehnoznanstvenoga oblikovanja »novih« svjetova? Lyotard je svoju sumnju u načelnu mogućnost održivosti ljudskosti iz biti metafizičkoga utemeljenja povijesti izveo polazeći upravo iz promišljanja onoga što je za postmoderni obrat ishodište. Nazvat ćemo to korporalnim obratom i odrediti ga ne više iz horizontalno postavljene tjelesnosti čovjeka s kojim je otpočela egzistencijalna fenomenologija Merleau-Pontyja. Sada je posrijedi ona vrsta tjelesnosti koja se može razumjeti tek iz susreta s posthumanizmom i transhumanizmom. Naravno, mišljenje tjelesnosti ne može se svesti na djelatnosti mozga-u-tijelu, na materijalnost i formalne strukture koje omogućuju gibanje tijela, osjećaje, doživljaje, perceptivne radnje i kognitivne procese. Tijelo, doduše, osjeća i pati. Ali bez njega mišljenje više ne može biti ljudsko-odveć-ljudsko. Lyotard je u tom pogledu »humanist« jer ne može filozofijski prijeći granice koje dijele ljudsko od neljudskoga. Problem postaje još teži kada znamo da je 
tjelesnost tijela u tehnogenetskome smislu ono što je posve zastarjelo, kako to, bez ikakvog kompleksa, iskazuje Stelarc, jedan od vodećih kibernetičkih suvremenih umjetnika:

»Više se ne radi o ovjekovječenju ljudske vrste reprodukcijom, već o usavršavanju muško-ženskih međuodnosa s pomoću sučelja čovjek-stroj. Tijelo je zastarjelo. Nalazimo se na kraju ljudske filozofije i ljudske fiziologije. $\ll^{50}$

\section{Sloboda i kibernetička razlika}

Misliti-bez-tijela jest moguće. I to je ono čemu je na putu tehnoznanstvena konstrukcija nadolazećih svjetova. Tijekom povijesti zapadnjačke metafizike tijelo je bilo žrtvovano posljednjoj svrsi duše/duha u svim filozofijsko-religijskim sustavima. Sloboda kao bezrazložnost bitka postaje događaj oslobađanja tijela od tamnice duševno-duhovnih »vježbi« pa nije začudno zašto s Nietzscheom otpočinje dugovječni proces emancipacije s dalekosežnim posljedicama za određenje »biti« čovjeka. Lyotard je, dakle, skeptički i stoički uspostavio granicu između ljudskoga i neljudskoga polazeći od fenomenologijski »zadane« granice mišljenja kao »utjelovljenja« (embodiement), a ne mišljenja kao »ugradnje/konstrukcije« (embedment). Treba imati na umu da su dvije razlike - ontologijska i kibernetička - međusobno korelativne, inače ne bi nikad moglo doći do prevlasti tehničkoga nihilizma nad razumijevanjem bitka kao otvorenosti događaja. Sloboda koja omogućuje mišljenju njegovo eksperimentiranje u igri s kontingencijama i kaosom, nije ni bitak, ni biće. Od Schellinga preko Heideggera do svih postmodernih mislilaca uvijek je ista razvojna crta: biti slobodan znači biti neodređen, neomeđen, neograničen slijepom nužnošću zbivanja. Povijesno događanje kao mišljenje označava događanje slobode. Bez nje ni filozofija, ni umjetnost ne bi imale smisla. Kada povijest u svojem lutanju bez kraja postane ovo gibanje u bezgraničnosti i beskonačnosti, svrha i cilj nisu više bjelodani. U stanju postmodernoga obrata susrećemo se, stoga, s posve drukčijim likom nihilizma, negoli je to bilo uobičajeno još za Nietzschea i Heideggera. Sada se nihilizam »naselio« u samo mišljenje kao stvaralačko oslobađanje od nužnosti ontogeneze.

Biti i egzistirati kao »nadčovjek « pretpostavlja da je logika »imanentne transcendencije« načelo proizvođenja »novoga«. Razlog zašto je to tako proizlazi iz sustavne analogije prema kojoj ono što je bilo zbiljsko za prethodni model mišljenja postaje moguće i nužno za sadašnji. Ne može se nipošto otkloniti ova ontologijska »zamjenična igra« iz perspektive mišljenja kao eksperimenta s obratom ili preokretom metafizike. No, za razliku od Heideggera i njegove analize Nietzscheova mišljenja polazeći od »volje za moć kao umjetnosti«, vidimo da je tehnogeneza onaj način stvaranja »novoga« koji u sebi obuhvaća dva temeljna pojma postmoderne: transgresiju i dekonstrukciju bitka kao »prirode« (physis). Estetsko je uklopljeno u ono znanstveno kao takvo jer se »bit« novoga stvaranja svjetova nije više ne izvodi nikako drukčije negoli autopoietički. To je nihilizam koji više izvan ovoga svijeta ili, pak, unutar njega,

49

Ž. Paić, Posthumano stanje, str. 44.

50

Stelarc, Ping Body. Dostupno na: http:// www.medienkunstnetz.de/works/ping-body/ (pristupljeno 14. 4. 2021.). Vidi o tome:
Žarko Paić, „Synaesthetic Without Sensitivity? The Body as a Technological Construction«, Philosophy Study 9 (2019) 6, str. 333-354, doi: https://doi.org/10.17265/21595313/2019.06.004. 
već je samo Ništa u središtu svijeta. Vanja Sutlić na kraju Biti i suvremenosti kaže:

»Van 'kruga' ovog svijeta [...] leži 'ništa', i to ovaj svijet pri povratku u 'krug' čini tako familijarnim, skrovitim i pouzdanim makar koliko inače bio kompliciran. Ali nije on samo van tog 'kruga': 'ništa' je i u srži ovog svijeta jer se on održava samo dinamikom stalnog obnavljanja i od početka prijeti da rastvori strukturu ovog svijeta. $\aleph^{51}$

\section{Zaključak}

Nihilizam »novoga« tipa polazi od pragmatike znanja i performativnosti tehničkoga jezika čija je »bit« sadržana u vizualizaciji događaja. Slika otuda prethodi jeziku kao što pisanje prethodi govoru. To je konačan rezultat postmodernoga obrata, a ne već dosadne »male priče« o stilskim tendencijama između visoke i masovne kulture u svim područjima »duhovnoga bitka«. Biti otuda za »modernu« ili »postmodernu« posve je beznačajan čin misaonoga izbora između onoga što već uvijek »jest« ili »postaje i biva« drukčijim. Iluzija je očekivati ono spasonosno tek kao nadu da je filozofijsko mišljenje u stanju preusmjeriti tijek planetarno-globalne povijesti. Uostalom, ono što obilježava duh raspršenosti i relativizma vrijednosti postmoderne ponajbolje se očituje u slobodi kao izboru. No, za razliku od Sartreova egzistencijalizma kao humanizma u kojem čovjek biva prisiljen izabrati u tjeskobnome činu »svoju« slobodu u situacijama, što neizbježno dovodi do apsurda, sada je izbor načelno »lakši« jer se bira između alternativa. Paradoks i aporija slobode kao izbora, stoga, proizlazi otuda što je izbor već unaprijed izabran u mnoštvu pseudo-mogućnosti koje stoje pred singularnim pojedincem. Zanimljivo je, pritom, da čak i sociologijska teorija »racionalnoga izbora « (rational-choice theory), kao legitimno opravdanje neoliberalizma, počiva na ovoj »tiraniji pluralnosti izbora«, što nužno stvara probleme da izbor naposljetku postaje karikatura slobode - izbor »stila života« (lifestyle).

Pravi je problem ipak u tome može li se uopće tehnosferi stvoriti neka suvisla i dostatno »moćna « alternativa koja će imati izglede ne da »prevlada« ili »pregori/preboli« ovaj svijet koji gubi naočigled naših težnji bilo kakav smisao i tone u najdublju moguću ravnodušnost spram bitka, biti čovjeka i bića u cjelini, spram bezuvjetno Drugoga. Za tako nešto ni »dekonstrukcija«, ni »slabo mišljenje«, a ponajmanje različite politike estetskoga otpora nisu više mjerodavne orijentacije mišljenja. Kao što je »moć« istoznačna od samoga početka s ovladavanjem bitka, a bitak sâm izjednačen sa »življenjem«, tako se jezik kao događaj kazivanja svijeta mora osloboditi straha od pada u tehnički bezdan. Moć kao življenje urgentno iziskuje »novi jezik« osmišljavanja svijeta, premda su izgledi za to sve više i više ne-izgledni. Zašto?

Zbog toga što ništa više ne može zaustaviti tehnogenezu na putu u nihilizam čiste singularnosti. Kada, naizgled, sve savršeno funkcionira u ovome svijetu, kada se »novo" proizvodi kao događaj čiste kontingencije, pojavljuje se crv tjeskobe u onome što je preostalo od ljudskoga bitka. Zanesenost simulacijom zbilje koja je postala hiperrealnom pustinjom »koja se širi«, odjednom nema više značajke posvemašnje vjere u beskonačni »napredak«. Heidegger je na to još 1950-ih godina upozoravao kada je paradigma moderne tehnologije bila primijenjena atomska fizika. Opasnost, pritom, ne leži u primijenjenoj znanosti, već u mišljenju koje osvaja i prisvaja bitak kao »svoje« vlasništvo. Uz to, takvo mišljenje poprima militarne značajke neovisno od toga što netko sebe smatra »humanistom« ili »antihumanistom«. Zbog toga se čini da je 
mišljenje nadolazećega događaja s onu stranu svake modernosti-postmodernosti posljednji zalog očuvanja dostojanstva jezika svedenog na pragmatiku ništavila. Kada sve postaje, bodrijarovski rečeno, »integralna stvarnost« ili sintetički stvorena konfiguracija umjetnoga života ( $A$-life), tada ono što još preostaje od mišljenja kao događaja još-ne-viđene svjetovnosti svijeta pripada eksperimentu samoga »življenja« kao egzistencijalnoga projekta slobode, kako su to dobro znali grčki stoici. Život se očigledno mora početi razmatrati u binarnim oprekama živo-umjetno, a ne živo i ne-živo. Ipak, ono prvo i posljednje nije u tome zadivljenost ništavilom tehnosfere. Ono prvo i posljednje znači očuvanje dostojanstva »življenja« pred nihilizmom ovoga doba koje je ostalo bez povijesti i njoj primjereno dostojnoga smisla.

\title{
Žarko Paić
}

\section{Nihilism and History}

\section{What Remained of Postmodernity?}

\section{Abstract}

The paper establishes a correlation between nihilism and history from the premise of the end of metaphysics in the age of the technosphere. In presenting the genealogy of the postmodern turn in contemporary philosophical thinking, the author critically deals with Vattimo's thesis that Heidegger's notion of overcoming metaphysics (Verwindung) is the key to understanding postmodernity. Despite its close proximity to Nietzsche and Heidegger, it is undeniable that the main notion must be derived from late Wittgenstein's thinking, as Lyotard did in his analysis of the "postmodern condition". It is a notion of "language games" that introduces into consideration the relationship between the pragmatics of knowledge, the performativity of language and the event horizon. In this way, it will be shown that postmodernity cannot be any "new" epoch but rather a re-actualization of the condition determined by the rule of technoscience, cybernetics and plural patterns of culture in post-industrial society. Based on his previous analyses of this problem, collected in the books The Postmodern Game of the World, Identity Politics. The Posthuman Condition, and Technosphere $\mathrm{I}-\mathrm{V}$, the author believes that only extensive analysis and interpretation of Lyotard's premises allows one to reach the right philosophical path to the answer to the question of the essence of nihilism in the face of Being, and the technosphere as computation, planning, and construction of the inhuman. In contemporary times, what is left of postmodernity is neither "telling stories" about the stylistic tendencies of the modern and neomodern, the avant-garde and the neo-avant-garde, nor, moreso, the conflict of the universality and particularity of society and culture. All that remains is the feature of the unwavering "fate" of this nihilism of the technosphere: from the postmodern condition to the posthuman condition, thought is confronted with the challenge of an event that goes beyond anything seen in the history of Western metaphysics. When the image precedes the language and the writing to speaking, we find ourselves in a closed circle of turns and reversals of metaphysics. It is time to step out of this "vicious circle" in which the living becomes non-living, the Being becomes the information, the system of objects replaces society, and the human-too-human with inhuman as such.
\end{abstract}

\section{Keywords}

postmodern turn, nihilism, language games, pragmatics of knowledge, posthuman condition, Jean-François Lyotard, technosphere 